\title{
THE ENCAPSULATION OF POWDERED DOUM EXTRACT IN LIPOSOMES AND ITS APPLICATION IN YOGHURT
}

\author{
Marwa M. El-Said, Tamer M. El-Messery ${ }^{\bowtie}$, Hala M. F. El-Din \\ Dairy Department, Food Industries and Nutrition Division, National Research Centre, Egypt
}

\begin{abstract}
Background. Doum fruit extract has many dietary benefits, but, due to the potential interaction between its phenolic compounds and milk proteins, its antioxidant activity is reduced in dairy formulations. To overcome this problem, encapsulation in liposomes has been used to improve the bioavailability of the phenolic compounds by protecting them from oxygen and acids, creating the conditions for better delivery and controlling their release into the body.

Material and methods. A liposome was used to encapsulate doum extract powder (DEP), and the encapsulated DEP was used to fortify yoghurt. The physicochemical properties of the yoghurt produced, including $\mathrm{pH}$, acidity, water holding capacity and texture, were investigated in fresh yoghurt and after 21 days of storage at $4^{\circ} \mathrm{C}$.

Results. Adding 5\% DEP liposome to yoghurt gave a product with characteristics similar to the control sample but with higher antioxidant activity.

Conclusion. Doum extract powder has been successfully encapsulated in liposomes. The high encapsulation efficiency, particle size, and TEM examination indicate successful encapsulation of up to $1 \%$ DEP. The addition of 5\% DEP liposomes into yoghurt had some effects on the development of acidity, textural parameters, and water holding capacity of the yoghurt, compared to a control. The addition of higher percentages of DEP liposomes significantly affected the functional properties of yoghurt. It is recommended that $5 \%$ DEP liposomes can be added to yoghurt in order to increase its antioxidant activity.
\end{abstract}

Keywords: doum, encapsulate, phenolic compounds, liposome, yoghurt

\section{INTRODUCTION}

Yoghurt is one of the most popular fermented dairy products and is appreciated for its nutritional value and good digestibility (Saint-Eve et al., 2006). During recent decades, a global increase in yoghurt consumption has been witnessed thanks to its various benefits, including strengthening the immune system, improving bowel function, decreasing the risk of colon cancer and combating Helicobacter pylori infection (El-Abbadi et al., 2014). In order to improve the antioxidant activity of yoghurt, herbs, spices, and fruits and vegetables and their peels have been used as supplements to increase levels of antioxidants and phenolic compounds (Costa et al., 2017; Illupapalayam et al., 2014). Doum (Hyphaene thebaica) is a traditional tree in Egypt and its fruits are commonly consumed, both for its pleasant taste and as a rich source of phenolic compounds (Eldahshan et al., 2008; 2009; Katalinic et al., 2006). Besides its nutritional value, the water extract of doum has potential health effects, such as hypolipidemia in nephrotic 
syndrome and decreasing the risk of atherosclerosis and glomerulosclerosis. Also, it is used as a hematinic agent to combat in bilharziasis, hematuria and bleeding, especially after childbirth (Habib et al., 2014). Today, consumers are more aware of the health aspect of food consumption (Nothlings et al., 2007; Takachi et al., 2008). The World Health Organization (WHO), reported in 2003 that dietary habits and food choices are among the major risk factors for several diseases, such as cancer, coronary cardiovascular diseases and obesity. The addition of bioactive agents to food promoted the development of functional food. However, the effectiveness of these additives is complicated by many factors during processing, such as degradation, oxidation, and undesirable reactions with other food components during manufacture and storage, all of which can reduce their bioavailability and the total acceptability of the fortified food (Schrooyen et al., 2001). Rashidinejad et al. (2013) found that the availability of phenolic compounds added to yoghurt decreased due to interactions between phenolic compounds and milk proteins. These interactions were reported by Ozdal et al. (2013) and Haratifar and Corredig (2014), who pointed out that these interactions were the main reason for the reduced antioxidant activity of the added phenolic compounds. The encapsulation of bioactive agents has been attempted as a solution to this problem. Encapsulation also reduces the astringency of the added bioactive compounds in the functional foods, and one of the most interesting encapsulation technologies applied in foods is the formation of liposomes (Sun-Waterhouse et al., 2013). The encapsulation of active ingredients in liposomes can improve their bioavailability by protecting them against oxygen, acids, and processing conditions and the ability to disperse lipid compounds into an aqueous phase for better delivery and to control their release (Mozafari et al., 2008).

This study aimed to develop a functional dairy product (set yoghurt) supplemented with doum extract encapsulated in a liposome. The doum extract-loaded liposome was characterized (particle size, zeta potential, transmission electron microscope and encapsulation efficiency). Also, the physical and textural properties and encapsulation efficiency of the doum extract-loaded liposome in yoghurt were evaluated during storage.

\section{MATERIALS AND METHODS}

\section{Materials}

The doum fruits were bought from a local market in Cairo, Egypt. The edible part of the dried fruit was ground into a rough powder using a mortar. The soy lecithin $(69.3 \%$ phosphatidyl choline, $9.8 \%$ phosphatidylethanolamine, and $2.1 \%$ lysophosphatidylcholine) was provided by Lipoid AG (Ludwigshafen, Germany). Chitosan was obtained from Sigma (USA). Sodium acetate and acetic acid glacial were purchased from Carl Roth GmbH \& Co. KG (Karlsruhe, Germany). Folin-Ciocalteu reagent, Gallic acid and 1,1-diphenyl-2-pycrylhydrazyl (DPPH) were purchased from Sigma-Aldrich Co. (St. Louis, USA). Low-heat skimmed milk powder (USA) with $34 \%$ protein, $51 \%$ lactose, $1.2 \%$ fat, $8.2 \%$ ash and $4 \%$ moisture was used. Starter strains of Streptococcus thermophilus and Lactobacillus delburkii ssp. Bulgaricus were obtained from stock cultures from the Dairy Microbiology Lab., National Research Centre, Dokki, Cairo, Egypt, and propagated in sterilized reconstituted skimmed milk $(10 \% \mathrm{w} / \mathrm{v})$ before use.

\section{Doum fruit extract}

Portions of doum fruit powder $(2,4,6,8$ and $10 \mathrm{~g})$ were transferred to glass bottles, containing $100 \mathrm{ml}$ of distilled water at $25^{\circ} \mathrm{C}$ or $50^{\circ} \mathrm{C}$ for 30,60 min or soaked for $24 \mathrm{hrs}$ at room temperature with continuous stirring. All extracts were filtered by Whatman filter paper no. 1. The clear filtrate was collected and kept at $-20^{\circ} \mathrm{C}$ in dark bottles until used.

\section{Identification of phenolic and flavonoid compounds}

High-Performance Liquid Chromatography Measurement (HPLC) analysis was carried out using an Agilent 1260 series. The separation was carried out using a C18 column $(4.6 \mathrm{~mm} \times 250 \mathrm{~mm}$ i.d., $5 \mu \mathrm{m})$. The mobile phase consisted of water: $0.02 \%$ tri-floro-acetic acid in acetonitrile (80:20) at a flow rate $1 \mathrm{ml} / \mathrm{min}$. The multi-wavelength detector was monitored at $280 \mathrm{~nm}$. The injection volume was $10 \mu \mathrm{l}$ for each of the sample solutions. The column temperature was maintained at $35^{\circ} \mathrm{C}$. 


\section{Determination of total antioxidant activity (AA)}

The antioxidant activity was determined by the ability of antioxidants to scavenge DPPH (2, 2-diphenyl-1-picrylhydrazyl) as a free radical (Brand-Williams et al., 1995). The antioxidant activity was calculated using the following equation:

$$
\text { Antioxidant activity, } \%=\left(1-\frac{\mathrm{abs} \text { sample }}{\mathrm{abs} \text { control }}\right) \times 100
$$

\section{Determination of total phenolic content (TPC)}

Total phenolic content was determined according to Jayaprakasha et al. (2001) using Folin-Ciocalteu reagent. The results were expressed as milligrams Gallic acid equivalent per gram of dry weight.

\section{Freeze-drying of doum extract}

The doum extracts were frozen at $-18^{\circ} \mathrm{C}$ and then freeze dried using a freeze dryer (Christ, Alpha 1-2 LD plus, Osterode, Germany) at $-52^{\circ} \mathrm{C}$ for $48 \mathrm{hr}$, at pressure below $0.1 \mathrm{mPa}$. The dried extract was manually ground to fine powder and kept at $-18^{\circ} \mathrm{C}$ until encapsulation and analysis.

\section{Encapsulation of doum extract powder (DEP) in a liposome}

Lecithin powder (2\%) was dissolved in $100 \mathrm{ml}$ acetate buffer $(250 \mathrm{mM}, \mathrm{pH} 3.5 \pm 0.1)$ and stirred overnight to ensure full dissolution and homogeneity. Various concentrations of DEP $(0.2,0.4,0.6,0.8$ and $1 \%)$ were added to the lecithin solutions. Chitosan $(0.08 \%, \mathrm{w} / \mathrm{v})$ was prepared by dissolving it in an acetate buffer, then added to the lecithin with DEP solution and homogenized using ultrasonication $(160 \mathrm{~W}$ power, $20 \mathrm{kHz}$ frequency and with $50 \%$ pulse; Sonics, Vibra, Cell, USA) for 5 min (Gültekin-Özgüven et al., 2016).

\section{Liposome characterizations}

Measurements of particle size distribution and zeta potential. The particle size and zeta potential were determined with a dynamic light scattering instrument (Nano ZS, Malvern Instruments, Worcestershire, UK). The refractive index for lecithin was 1.37 \pm 0.02 . The liposomal solutions were diluted to concentrations of $0.1 \%(\mathrm{w} / \mathrm{w})$ before measurement.
Transmission electron microscope (TEM). Twenty microliters of diluted samples were placed on a filmcoated 200-mesh copper specimen grid for $10 \mathrm{~min}$ and the excess fluid was removed using filter paper. The grid was then stained with one drop of $3 \%$ phosphotungstic acid and allowed to dry for $3 \mathrm{~min}$. The coated grid was dried and examined under the TEM microscope (JEM-2100 Electron Microscope), at $160 \mathrm{kV}$ (Saloko et al., 2013).

Encapsulation efficiency (EE). The dialysis tube diffusion technique was used to determine EE. One aliquot of $5 \mathrm{ml}$ of the liposome suspension was placed in the dialysis tube, closed tightly and dialyzed against an acetate buffer at $37^{\circ} \mathrm{C}$, with continuous stirring. Samples were taken from the dialysate at successive intervals and assayed for total free phenolic compounds (FPC). Encapsulation efficiency \% was calculated by the following equation:

Encapsulation efficiency $(\mathrm{EE})=\left(\frac{\mathrm{TPC}-\mathrm{FCP}}{\mathrm{TPC}}\right) \times 100$

where:

TPC - total phenolic content,

FPC - free phenolic compounds.

\section{Yoghurt preparation}

Skimmed milk powder (12\%) was reconstituted in distilled water. DEP-liposome solution $(0.8 \%$ DEP) was used to replace $5,10,15$ and $20 \%$ of the water used for reconstitution, except in the control. All milks were heated to $90^{\circ} \mathrm{C}$ for $10 \mathrm{~min}$ and cooled to $40^{\circ} \mathrm{C}$. Starter cultures $(3 \%$; S. thermophilus and $l b$. delburkii ssp. bulgaricus) were added and the inoculated milks were poured into cups $(100 \mathrm{ml})$ and incubated at $45^{\circ} \mathrm{C}$ until complete curd formation. All yoghurt cups were stored in a refrigerator $\left(6 \pm 2^{\circ} \mathrm{C}\right)$ and analyzed when fresh and after 21 days of storage.

\section{Physicochemical characteristics of yoghurt}

Acidity and pH measurement. The titratable acidity of the yoghurt was measured according to the 942.15 AOAC methods (2000), and the results were expressed as $\%(\mathrm{w} / \mathrm{w})$ of lactic acid. The $\mathrm{pH}$ was measured using a pH meter (JENWAY 3505) equipped with combined electrode. 
Water holding capacity (WHC) was determined according to Arslan and Özel (2012). The WHC \% was calculated using the following equation:

where:

$$
\mathrm{EE}=\left(\frac{\mathrm{NY}-\mathrm{WE}}{\mathrm{NY}}\right) \times 100
$$

NY - weight of native yoghurt,

$\mathrm{WE}$ - weight of whey expelled.

Texture profile analysis (TPA) was carried out for yoghurt samples using the double compression test (Multi-test 1d Memesin, Food Technology Corporation, Slinfold, W. Sussex, UK). The experiments were carried out at room temperature, using a compression test to generate a plot of force $[\mathrm{N}]$ versus time [s]. A $25 \mathrm{~mm}$ diameter perplex conical probe was used to perform the TPA analysis of samples at five different points on the sample surface. In the 1st stage, the samples were compressed by $30 \%$ of their original depth at a speed of $2 \mathrm{~cm} / \mathrm{min}$ throughout pretest, compression and relaxation of the sample. From the force-time curve, the following parameters were determined according to the definition given by the International Dairy Federation (IDF, 1991), hardness $[\mathrm{N}]=$ maximum force of the $1^{\text {st }}$ compression.

- cohesiveness $=$ area under the $2^{\text {nd }}$ compression $/$ area under the $1^{\text {st }}$ compression $(A 2 / A 1)$

- adhesiveness, $\mathrm{N} \cdot \mathrm{s}=$ negative area under the curve $(A 3)$

- springiness, $\mathrm{mm}=$ length $2^{\text {nd }}$ compression $/$ length $1^{\text {st }}$ compression $(L 2 / L 1)$

- gumminess, $\mathrm{Ng}=$ hardness $\times$ cohesiveness

- chewiness, $(\mathrm{mJ}) \mathrm{g} / \mathrm{mm}=$ gumminess $\times$ springiness

\section{Statistical analyses}

The data obtained in this study was expressed as the mean of the results of three repetitions of the experiment. Statistical comparisons were made using Duncan's test, which was analyzed with SPSS (SPSS for Windows, Version Rel. 15.0, 2006, SPSS Inc.). $P$ values $<0.05$ were considered to be significant.

\section{RESULTS AND DISCUSSION}

\section{Identification of phenolic and flavonoid compounds by HPLC}

The HPLC method was used for the identification of individual phenolic compounds extracted from doum.
Table 1. HPLC of phenolic compounds identified in doum extract

\begin{tabular}{lc}
\hline Phenolics group & $\begin{array}{c}\text { Concentration of phenolic compounds, } \\
\mu \mathrm{g} / \mathrm{g}\end{array}$ \\
\hline Coffeic acid & 28.89 \\
Coumaric acid & 6.11 \\
Naringenin & 991.86 \\
Cinnamic acid & 6.87 \\
\hline
\end{tabular}

Table 1 shows the names and concentrations of 4 phenolic compounds in doum fruit aqueous extracts. Thirteen phenolic compounds used as standards are listed, with retention times and absorbance ratios. All these standards were determined by their spectral properties (Fig. 1). The most common phenolic compound in doum extract was Naringenin $(991.86 \mu \mathrm{g} / \mathrm{g})$, while the lowest concentrations were of Cinnamic Acid and Coumaric Acid (6.87 and $6.11 \mu \mathrm{g} / \mathrm{g}$ respectively) Aamer (2016).

\section{Antioxidant activity (AA) and total phenolic contents (TPC) of doum extracts}

The antioxidant activities of compounds in doum extract were measured by their ability to donate hydrogen to the scavenging the DPPH free-radical (Chen and Ho, 1995). The results in Table 2 show the effect of extraction conditions on the AA\% and TPC values of doum extract. The mean values of AA\% and TPC increased as the concentration of doum extracted increased, which may be attributed to the increased concentration of phenolic compounds. Doum fruit has been reported to contain more than 14 polyphenolic compounds (Habib et al., 2014). Hsu et al. (2006) and Aboshora et al. (2014) stated that the water extract of doum fruit has potential antioxidant activity due to the extracted water-soluble phenolic compounds, in agreement with the present results. The highest AA and TPC content with water extract were attained when the extraction was carried out at $50^{\circ} \mathrm{C}$, compared to soaking and extraction at $25^{\circ} \mathrm{C}$. In all cases, the extracted AA and TPC increased with increasing the extraction time. There are several factors that have been reported to affect the composition of plant extracts, such as temperature, extraction time, extraction method and the 
El-Said, M. M., El-Messery, T. M., El-Din, H. M. F. (2018). The encapsulation of powdered doum extract in liposomes and its application in yoghurt. Acta Sci. Pol. Technol. Aliment., 17(3), 235-245. http://dx.doi.org/10.17306/J.AFS.2018.0571

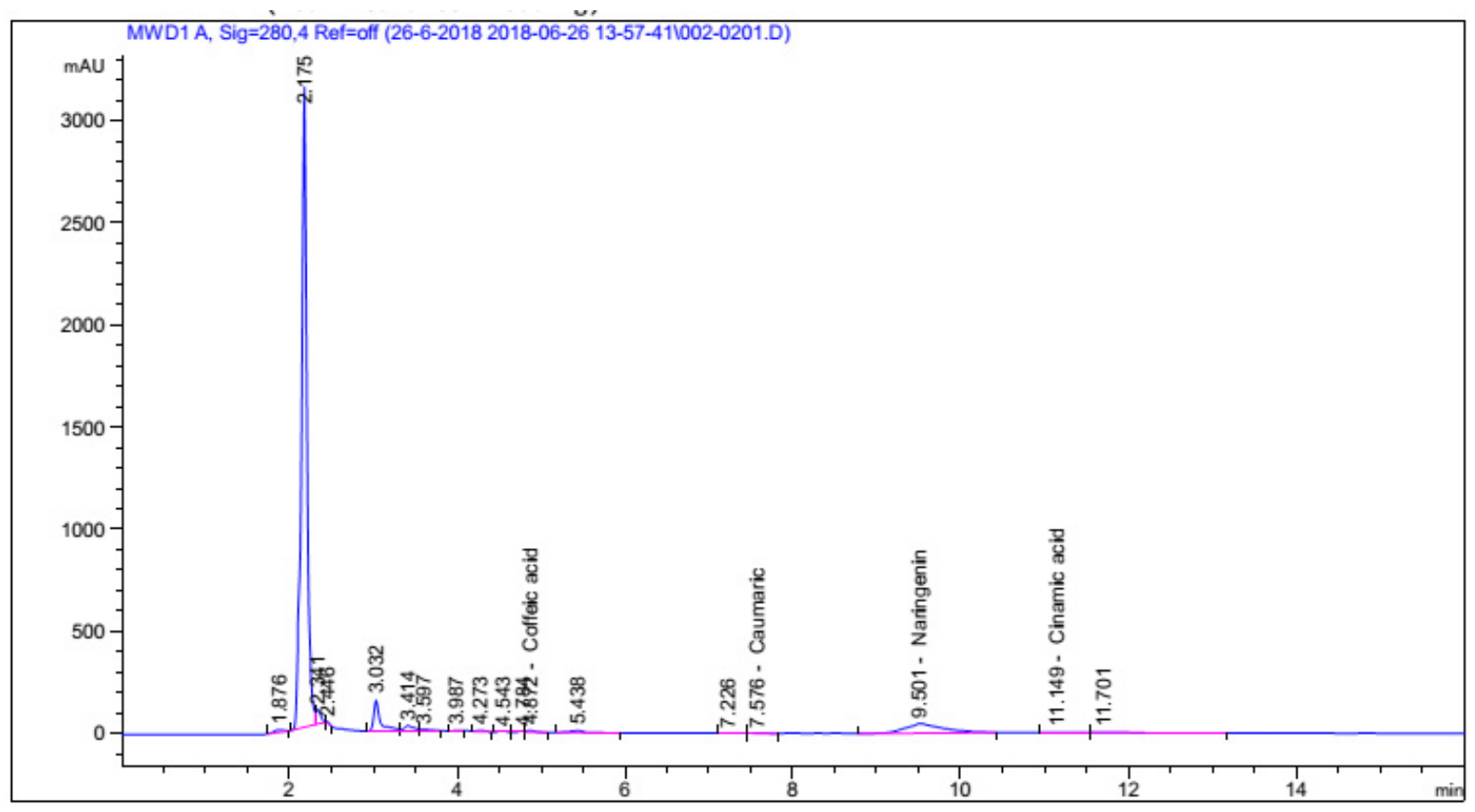

Fig. 1. HPLC of phenolic compounds identified in doum extract

Table 2. Antioxidant activity (AA) \% and TPC (mg Gallic acid/g) of doum extract with different treatments (soaking, room temperature and $50^{\circ} \mathrm{C}$ ) at $0,15,30$ and $60 \mathrm{~min}$

\begin{tabular}{|c|c|c|c|c|c|c|c|c|c|c|}
\hline \multirow{2}{*}{ Treatments } & \multicolumn{5}{|c|}{ Concentration of extract, $\%$} & \multicolumn{5}{|c|}{ Concentration of extract, $\%$} \\
\hline & 2 & 4 & 6 & 8 & 10 & 2 & 4 & 6 & 8 & 10 \\
\hline & \multicolumn{5}{|c|}{$\mathrm{AA}, \%$} & \multicolumn{5}{|c|}{ TPC, mg Gallic acid/g } \\
\hline \multirow[t]{4}{*}{1} & 2 & 3 & 4 & 5 & 6 & 7 & 8 & 9 & 10 & 11 \\
\hline & \multicolumn{5}{|c|}{ soaking $-24 \mathrm{~h}$} & \multicolumn{5}{|c|}{ soaking $-24 \mathrm{~h}$} \\
\hline & $\begin{array}{l}66.85 \\
\pm 1.86^{\mathrm{b}}\end{array}$ & $\begin{array}{l}89.26 \\
\pm 1.06^{\mathrm{b}}\end{array}$ & $\begin{array}{l}93.60 \\
\pm 0.13^{\mathrm{a}}\end{array}$ & $\begin{array}{l}93.83 \\
\pm 0.28^{\mathrm{a}}\end{array}$ & $\begin{array}{l}94.15 \\
\pm 0.05^{\mathrm{a}}\end{array}$ & $\begin{array}{c}180.30 \\
\pm 0.28^{\mathrm{e}}\end{array}$ & $\begin{array}{c}272.30 \\
\pm 2.40^{\mathrm{d}}\end{array}$ & $\begin{array}{c}316.35 \\
\pm 3.18^{\mathrm{c}}\end{array}$ & $\begin{array}{l}392.50 \\
\pm 1.41^{\mathrm{b}}\end{array}$ & $\begin{array}{c}409.45 \\
\pm 0.49^{\mathrm{a}}\end{array}$ \\
\hline & \multicolumn{5}{|c|}{$25^{\circ} \mathrm{C}$} & \multicolumn{5}{|c|}{$25^{\circ} \mathrm{C}$} \\
\hline Zero time & $\begin{array}{l}33.61 \\
\pm 0.48^{\mathrm{Dd}}\end{array}$ & $\begin{array}{l}47.92 \\
\pm 0.68^{\mathrm{Bc}}\end{array}$ & $\begin{array}{l}79.22 \\
\pm 0.77^{\mathrm{Bb}}\end{array}$ & $\begin{array}{l}90.95 \\
\pm 1.28^{\text {Aa }}\end{array}$ & $\begin{array}{l}91.69 \\
\pm 2.22^{\text {Aa }}\end{array}$ & $\begin{array}{l}154.45 \\
\pm 0.49^{\mathrm{De}}\end{array}$ & $\begin{array}{l}222.15 \\
\pm 0.07^{\mathrm{Cd}}\end{array}$ & $\begin{array}{l}288.30 \\
\pm 0.00^{\mathrm{Cc}}\end{array}$ & $\begin{array}{l}321.50 \\
\pm 2.83^{\mathrm{Cb}}\end{array}$ & $\begin{array}{l}383.50 \\
\pm 3.54^{\mathrm{Ba}}\end{array}$ \\
\hline $15 \mathrm{~min}$ & $\begin{array}{l}36.37 \\
\pm 1.02^{\mathrm{Cc}}\end{array}$ & $\begin{array}{l}71.92 \\
\pm 0.17^{\mathrm{Ab}}\end{array}$ & $\begin{array}{l}88.37 \\
\pm 3.77^{\text {Aa }}\end{array}$ & $\begin{array}{l}91.88 \\
\pm 0.96^{\text {Aa }}\end{array}$ & $\begin{array}{l}92.06 \\
\pm 0.01^{\mathrm{Aa}}\end{array}$ & $\begin{array}{l}168.95 \\
\pm 1.48^{\mathrm{Ce}}\end{array}$ & $\begin{array}{l}235.25 \\
\pm 5.59^{\mathrm{Bd}}\end{array}$ & $\begin{array}{l}288.30 \\
\pm 0.00^{\mathrm{Cc}}\end{array}$ & $\begin{array}{l}343.60 \\
\pm 0.42^{\mathrm{Bb}}\end{array}$ & $\begin{array}{c}383.65 \\
\pm 0.78^{\mathrm{Ba}}\end{array}$ \\
\hline $30 \mathrm{~min}$ & $\begin{array}{l}41.92 \\
\pm 0.04^{\mathrm{Db}}\end{array}$ & $\begin{array}{l}72.01 \\
\pm 1.72^{\mathrm{Ac}}\end{array}$ & $\begin{array}{l}89.46 \\
\pm 0.14^{\mathrm{Ab}}\end{array}$ & $\begin{array}{l}91.96 \\
\pm 0.02^{\text {Аa }}\end{array}$ & $\begin{array}{l}92.15 \\
\pm 0.82^{\mathrm{Aa}}\end{array}$ & $\begin{array}{l}164.15 \\
\pm 2.19^{\mathrm{Be}}\end{array}$ & $\begin{array}{l}235.75 \\
\pm 0.35^{\text {Bd }}\end{array}$ & $\begin{array}{l}301.50 \\
\pm 0.42^{\mathrm{Bc}}\end{array}$ & $\begin{array}{l}336.70 \\
\pm 6.22^{\mathrm{ABb}}\end{array}$ & $\begin{array}{l}383.65 \\
\pm 0.35^{\text {Ва }}\end{array}$ \\
\hline $60 \mathrm{~min}$ & $\begin{array}{l}60.07 \\
\pm 1.23^{\mathrm{Ca}}\end{array}$ & $\begin{array}{l}72.78 \\
\pm 1.89^{\mathrm{Ab}}\end{array}$ & $\begin{array}{l}90.42 \\
\pm 0.11^{\text {Aa }}\end{array}$ & $\begin{array}{l}91.94 \\
\pm 0.03^{\text {Aa }}\end{array}$ & $\begin{array}{l}92.79 \\
\pm 0.54^{\text {Aa }}\end{array}$ & $\begin{array}{c}178.00 \\
\pm 0.28^{\mathrm{Ae}}\end{array}$ & $\begin{array}{c}293.70 \\
\pm 3.96^{\mathrm{Ad}}\end{array}$ & $\begin{array}{c}309.60 \\
\pm 3.68^{\mathrm{Ac}}\end{array}$ & $\begin{array}{c}347.60 \\
\pm 0.57^{\mathrm{Ab}}\end{array}$ & $\begin{array}{c}395.30 \\
\pm 6.65^{\mathrm{Aa}}\end{array}$ \\
\hline
\end{tabular}


El-Said, M. M., El-Messery, T. M., El-Din, H. M. F. (2018). The encapsulation of powdered doum extract in liposomes and its application in yoghurt. Acta Sci. Pol. Technol. Aliment., 17(3), 235-245. http://dx.doi.org/10.17306/J.AFS.2018.0571

Table 2 - cont.

\begin{tabular}{|c|c|c|c|c|c|c|c|c|c|c|}
\hline 1 & 2 & 3 & 4 & 5 & 6 & 7 & 8 & 9 & 10 & 11 \\
\hline & & & $50^{\circ} \mathrm{C}$ & & & & & $50^{\circ} \mathrm{C}$ & & \\
\hline Zero time & $\begin{array}{l}60.27 \\
\pm 3.18^{\mathrm{Cc}}\end{array}$ & $\begin{array}{l}90.96 \\
\pm 0.80^{\mathrm{Bb}}\end{array}$ & $\begin{array}{l}92.37 \\
\pm 0.55^{\text {Aa }}\end{array}$ & $\begin{array}{l}77.27 \\
\pm 1.48^{\mathrm{Ba}}\end{array}$ & $\begin{array}{l}92.11 \\
\pm 0.89^{\text {Aa }}\end{array}$ & $\begin{array}{l}200.00 \\
\pm 0.28^{\mathrm{De}}\end{array}$ & $\begin{array}{l}334.85 \\
\pm 2.47^{\mathrm{Cd}}\end{array}$ & $\begin{array}{l}359.25 \\
\pm 0.78^{\mathrm{Cc}}\end{array}$ & $\begin{array}{l}403.90 \\
\pm 2.12^{\mathrm{Cb}}\end{array}$ & $\begin{array}{l}414.50 \\
\pm 0.42^{\mathrm{Ca}}\end{array}$ \\
\hline $15 \mathrm{~min}$ & $\begin{array}{l}74.06 \\
\pm 0.07^{\mathrm{Bb}}\end{array}$ & $\begin{array}{l}92.36 \\
\pm 0.47^{\mathrm{Ba}}\end{array}$ & $\begin{array}{l}92.65 \\
\pm 0.93^{\text {Аa }}\end{array}$ & $\begin{array}{l}91.50 \\
\pm 0.85^{\mathrm{Aa}}\end{array}$ & $\begin{array}{l}92.17 \\
\pm 0.10^{\mathrm{Aa}}\end{array}$ & $\begin{array}{l}252.65 \\
\pm 0.35^{\mathrm{Ce}}\end{array}$ & $\begin{array}{l}341.60 \\
\pm 1.84^{\mathrm{Cd}}\end{array}$ & $\begin{array}{l}428.50 \\
\pm 0.57^{\mathrm{Bc}}\end{array}$ & $\begin{array}{l}463.45 \\
\pm 3.75^{\mathrm{Bb}}\end{array}$ & $\begin{array}{l}488.45 \\
\pm 0.64^{\mathrm{Ba}}\end{array}$ \\
\hline $30 \mathrm{~min}$ & $\begin{array}{l}81.97 \\
\pm 0.66^{\mathrm{Ab}}\end{array}$ & $\begin{array}{l}92.87 \\
\pm 0.65^{\mathrm{Aa}}\end{array}$ & $\begin{array}{l}93.25 \\
\pm 0.23^{\mathrm{Aa}}\end{array}$ & $\begin{array}{l}92.22 \\
\pm 0.88^{\mathrm{Aa}}\end{array}$ & $\begin{array}{l}92.78 \\
\pm 0.55^{\text {Aa }}\end{array}$ & $\begin{array}{l}264.50 \\
\pm 2.69^{\mathrm{Be}}\end{array}$ & $\begin{array}{l}363.65 \\
\pm 4.03^{\mathrm{Bd}}\end{array}$ & $\begin{array}{l}440.70 \\
\pm 4.38^{\mathrm{Ac}}\end{array}$ & $\begin{array}{l}466.65 \\
\pm 0.21^{\mathrm{ABb}}\end{array}$ & $\begin{array}{l}484.95 \\
\pm 0.78^{\mathrm{Ba}}\end{array}$ \\
\hline $60 \mathrm{~min}$ & $\begin{array}{l}84.66 \\
\pm 1.53^{\mathrm{Ab}}\end{array}$ & $\begin{array}{l}94.09 \\
\pm 0.51^{\mathrm{Aa}}\end{array}$ & $\begin{array}{l}93.25 \\
\pm 0.79^{\mathrm{Aa}}\end{array}$ & $\begin{array}{l}92.58 \\
\pm 0.04^{\mathrm{Aa}}\end{array}$ & $\begin{array}{l}92.94 \\
\pm 0.72^{\mathrm{Aa}}\end{array}$ & $\begin{array}{l}293.60 \\
\pm 4.38^{\mathrm{Ae}}\end{array}$ & $\begin{array}{l}399.00 \\
\pm 4.95^{\mathrm{Ad}}\end{array}$ & $\begin{array}{l}439.25 \\
\pm 1.63^{\mathrm{Ac}}\end{array}$ & $\begin{array}{l}471.55 \\
\pm 0.35^{\mathrm{Ab}}\end{array}$ & $\begin{array}{l}543.00 \\
\pm 4.81^{\mathrm{Aa}}\end{array}$ \\
\hline
\end{tabular}

${ }^{\mathrm{a}-\mathrm{b}}$ Means that data with the same letter in the same column are not significantly $(p<0.05)$ different.

${ }^{\mathrm{A}-\mathrm{B} M e a n s}$ that data with the same letter in the same column are not significantly $(p<0.05)$ different.

AA - antioxidant activity. TPC - total phenolic content.

interaction between these factors, all of which significantly influence the phenolic compounds in the extract (Falleh et al., 2012; Ksouri et al., 2009). The increased mean values of $\mathrm{AA}$ and $\mathrm{TPC}$ in the extract at $50^{\circ} \mathrm{C}$ may be attributed to the release of phenolic compounds from plant cell walls during heat treatment (Kim et al., 2006). The results revealed that the extracted AA increased with increasing levels of doum extract up to a certain concentration, but further increases gave no increase in the extracted AA or TPC. Thus, the extraction of $4 \%$ doum at $50^{\circ} \mathrm{C}$ for $15 \mathrm{~min}$ gave the highest $\mathrm{AA}$ and TPC and further increases in temperature did not significantly improve the AA or TPC in the extract.
This indicates that the extract reached maximum solubility of phenolic compounds under these conditions.

\section{Liposome characterizations}

Particle size and zeta potential of DEP-loaded liposome. The sizes of DEP-loaded liposomes were found to follow a normal distribution curve, with means ranging from $261 \mathrm{~nm}$ for liposomes containing $0.2 \%$ DEP up to $482 \mathrm{~nm}$ for liposomes containing 1\% DEP (Table 3 ). These results clearly indicate that increasing concentrations of DEP increased the amount of entrapped DEP. Gibis et al. (2012) stated that the size of the liposomes was dependent on the quality of the materials loaded

Table 3. Particle size, zeta potential and encapsulation efficiency (EE) \% of DEP-loaded liposome

\begin{tabular}{ccccc}
\hline $\begin{array}{c}\text { Concentration } \\
\text { of DEP-loaded liposome } \\
\%\end{array}$ & $\begin{array}{c}\text { Particle size } \\
\mathrm{nm}\end{array}$ & PDI & $\begin{array}{c}\text { Zeta potential } \\
\mathrm{mV}\end{array}$ & $\begin{array}{c}\text { Encapsulation } \\
\text { efficiency (EE) } \\
\%\end{array}$ \\
\hline 0.2 & $261.230 \pm 2.645^{\mathrm{e}}$ & $0.355 \pm 0.021^{\mathrm{d}}$ & $-20.30 \pm 0.141^{\mathrm{a}}$ & $70.41 \pm 1.35^{\mathrm{c}}$ \\
0.4 & $310.440 \pm 2.178^{\mathrm{d}}$ & $0.436 \pm 0.023^{\mathrm{b}}$ & $-20.35 \pm 0.495^{\mathrm{a}}$ & $73.20 \pm 1.80^{\mathrm{b}}$ \\
0.6 & $354.370 \pm 2.503^{\mathrm{c}}$ & $0.469 \pm 0.016^{\mathrm{a}}$ & $-21.55 \pm 0.071^{\mathrm{bc}}$ & $73.92 \pm 0.28^{\mathrm{b}}$ \\
0.8 & $399.625 \pm 1.662^{\mathrm{b}}$ & $0.425 \pm 0.022^{\mathrm{c}}$ & $-20.87 \pm 0.240^{\mathrm{b}}$ & $82.29 \pm 0.45^{\mathrm{a}}$ \\
1 & $482.920 \pm 3.917^{\mathrm{a}}$ & $0.085 \pm 0.035^{\mathrm{e}}$ & $-23.25 \pm 0.212^{\mathrm{c}}$ & $83.90 \pm 0.12^{\mathrm{a}}$ \\
\hline
\end{tabular}

The data represent the average value \pm standard deviation of three replicates from each sample. The different letters in the columns $(\mathrm{a}-\mathrm{b})$ represent statistically significant differences $(p<0.05)$.

PDI - polydispersity index. 
in the liposome, which explains the present finding. The particle distribution index (PDI) defines the particle distribution curve. The obtained results indicate almost the same PDI for the different percentages of the loaded DEP except for the largest (1\%), which showed a narrower size distribution of formed liposomes. Measurement of the zeta potential revealed similar values for liposomes loaded with different percentages of DEP. The results showed that material negatively charge was present with DEP. In all cases the liposomes carried enough negative charge to remain dispersed in the solution.

Encapsulation efficiency (EE) of doum liposome. Encapsulation efficiency (EE) is defined as the amount of core material which is encapsulated in the capsules. Table 3 shows the EE of doum extract liposome. The EEs were $70.41,73.20,73.92,82.29$ and $83.90 \%$ for $0.2,0.4,0.6,0.8$ and $1 \%$ doum extract respectively. It was found that there is no significant difference in EE between 0.8 and $1 \%$ doum extract.

Transmission electron microscope (TEM). Figure 2 shows the TEM micrograph of the DEP-loaded liposome with $0.8 \%$ DEP. The observed liposomes displayed a spherical shape, in agreement with the findings of Thompson and Singh (2006). The mean size of the observed liposomes ranged from $180 \mathrm{~nm}$ to $310 \mathrm{~nm}$, which were less than the mean sizes for the same liposomes as measured by laser scattering, i.e. $481 \mathrm{~nm}$. The samples were dried before the TEM examination, which led to shrinkage of the liposomes, which may explain the small sizes of the liposomes which were observed.

\section{Physicochemical characteristics of yoghurt sup-} plemented with doum liposome $\mathrm{pH}$ and acidity. Table 4 shows the changes in the $\mathrm{pH}$ and acidity values of the yoghurt samples during storage at $4^{\circ} \mathrm{C}$. The $\mathrm{pH}$ value of the control sample was lower than that of the samples supplemented with doum liposomes. The $\mathrm{pH}$ of the yoghurt from different treatments decreased slightly during storage. The acidity of fresh control yoghurt was significantly $(P<0.05)$ higher than that of yoghurt fortified with different percentages of DEP liposomes. The acidity of yoghurt from the control and different treatments increased during storage, but the rate of increase was more pronounced in the control. These results suggest that the addition of DEP liposomes slightly reduced the activity of the starter bacteria.

Water holding capacity (WHC) of yoghurt samples supplemented with different concentrations of DEP-loaded liposome. The yoghurt quality can be determined by several parameters, such as water holding capacity (WHC), which is one of the most important
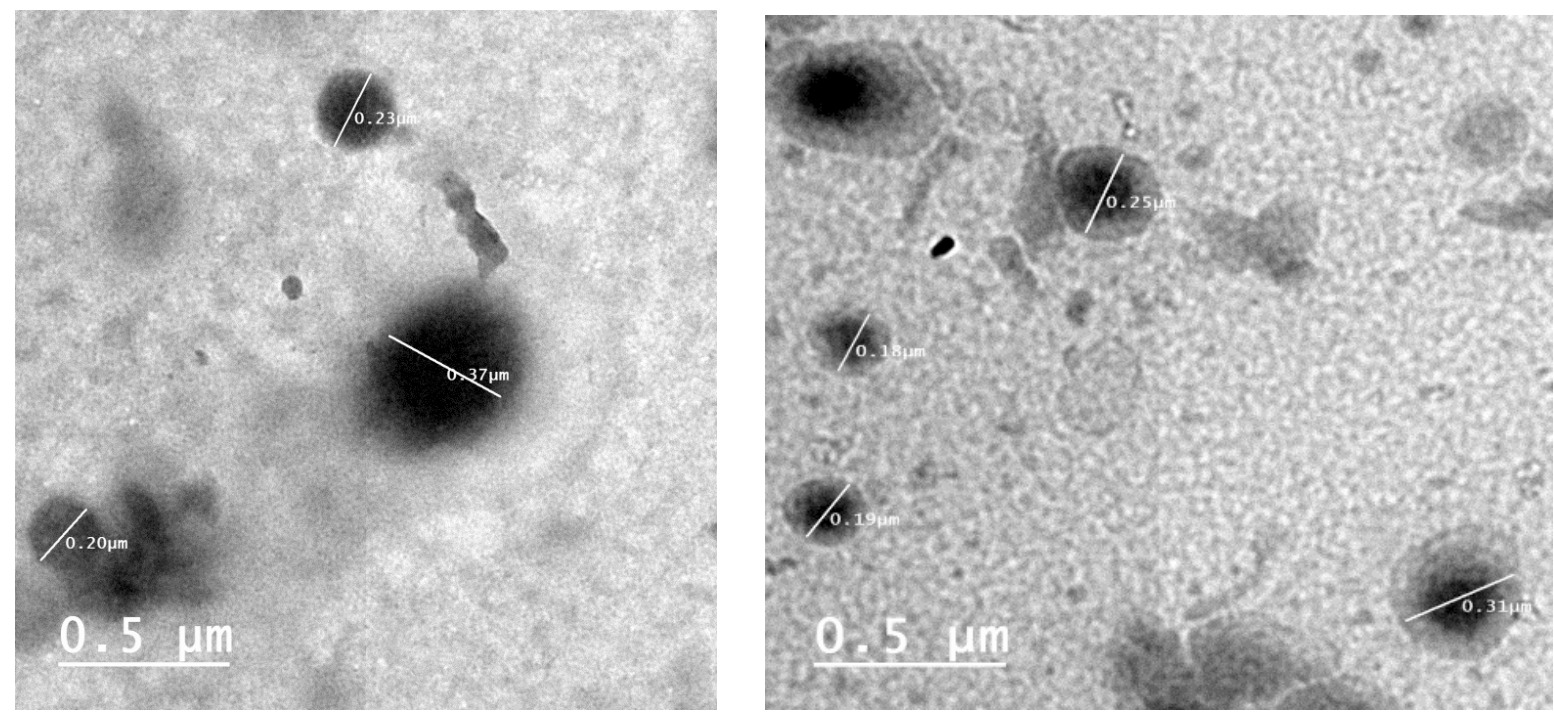

Fig. 2. TEM micrograph of DEP-loaded liposome with $0.8 \%$ DEP obtained at a scale of $0.5 \mu \mathrm{m}(500 \mathrm{~nm})$ 
El-Said, M. M., El-Messery, T. M., El-Din, H. M. F. (2018). The encapsulation of powdered doum extract in liposomes and its application in yoghurt. Acta Sci. Pol. Technol. Aliment., 17(3), 235-245. http://dx.doi.org/10.17306/J.AFS.2018.0571

Table 4. pH, acidity, TPC and WHC of yoghurt supplemented with different concentrations of DEP-loaded liposome

\begin{tabular}{|c|c|c|c|c|c|c|c|c|}
\hline \multirow{3}{*}{$\begin{array}{c}\text { Concentration } \\
\text { of DEP-loaded } \\
\text { liposome } \\
\%\end{array}$} & \multicolumn{2}{|c|}{$\mathrm{pH}$} & \multicolumn{2}{|c|}{$\begin{array}{c}\text { Acidity } \\
\%\end{array}$} & \multicolumn{2}{|c|}{$\begin{array}{c}\text { TPC } \\
\text { equivalent } \mathrm{mg} \text { Gallic } \\
\text { acid/g }\end{array}$} & \multicolumn{2}{|c|}{$\begin{array}{c}\text { WHC } \\
\%\end{array}$} \\
\hline & \multicolumn{8}{|c|}{ storage period, day } \\
\hline & fresh & 21 & fresh & 21 & fresh & 21 & fresh & 21 \\
\hline Control & $\begin{array}{c} \\
4.62 \\
\pm 0.02^{\mathrm{b}}\end{array}$ & $\begin{aligned} & 4.56 \\
\pm & 0.01^{\mathrm{c}}\end{aligned}$ & $\begin{array}{r}1.28 \\
\pm 0.00^{\mathrm{a}}\end{array}$ & $\begin{array}{c}1.67 \\
\pm 0.04^{\mathrm{a}}\end{array}$ & $\begin{array}{c}186.15 \\
\pm 0.35^{\mathrm{e}}\end{array}$ & $\begin{array}{c}194.35 \\
\pm 2.62^{\mathrm{d}}\end{array}$ & $\begin{array}{l}60.00 \\
\pm 0.00^{\mathrm{c}}\end{array}$ & $\begin{array}{l}53.30 \\
\pm 2.12^{\mathrm{c}}\end{array}$ \\
\hline 5 & $\begin{array}{c} \\
4.64 \\
\pm 0.03^{\mathrm{ab}}\end{array}$ & $\begin{array}{c}4.59 \\
\pm 0.01^{\mathrm{c}}\end{array}$ & $\begin{array}{c}1.26 \\
\pm 0.00^{\mathrm{ab}}\end{array}$ & $\begin{array}{c}1.31 \\
\pm 0.01^{\mathrm{b}}\end{array}$ & $\begin{array}{c}190.65 \\
\pm 0.49^{d}\end{array}$ & $\begin{array}{c}198.4 \\
\pm 0.99^{c}\end{array}$ & $\begin{array}{l}60.00 \\
\pm 0.00^{\mathrm{b}}\end{array}$ & $\begin{array}{l}51.50 \\
\pm 0.71^{\mathrm{bc}}\end{array}$ \\
\hline 10 & $\begin{array}{c}4.66 \\
\pm 0.01^{\mathrm{ab}}\end{array}$ & $\begin{array}{c}4.62 \\
\pm 0.01^{\mathrm{b}}\end{array}$ & $\begin{array}{c}1.22 \\
\pm 0.03^{\mathrm{bc}}\end{array}$ & $\begin{array}{c}1.27 \\
\pm 0.01^{\mathrm{b}}\end{array}$ & $\begin{array}{l}203.25 \\
\pm 0.354^{\mathrm{c}}\end{array}$ & $\begin{array}{c}212.45 \\
\pm 0.35^{\mathrm{b}}\end{array}$ & $\begin{array}{l}43.50 \\
\pm 2.12^{b}\end{array}$ & $\begin{array}{l}42.00 \\
\pm 0.00^{\mathrm{b}}\end{array}$ \\
\hline 15 & $\begin{array}{c}4.68 \\
\pm 0.01^{\mathrm{a}}\end{array}$ & $\begin{array}{c}4.66 \\
\pm 0.01^{\mathrm{ab}}\end{array}$ & $\begin{array}{c}1.19 \\
\pm 0.01^{\mathrm{c}}\end{array}$ & $\begin{aligned} & 1.25 \\
\pm & 0.01^{\mathrm{b}}\end{aligned}$ & $\begin{array}{l}208.85 \\
\pm 0.495^{\mathrm{b}}\end{array}$ & $\begin{array}{l}214.05 \\
\pm 0.495^{\mathrm{b}}\end{array}$ & $\begin{array}{l}43.50 \\
\pm 2.12^{\mathrm{a}}\end{array}$ & $\begin{array}{l}39.00 \\
\pm 1.41^{\mathrm{a}}\end{array}$ \\
\hline 20 & $\begin{array}{c}4.69 \\
\pm 0.02^{\mathrm{a}}\end{array}$ & $\begin{array}{c}4.68 \\
\pm 0.01^{\mathrm{a}}\end{array}$ & $\begin{array}{c}1.18 \\
\pm 0.01^{\mathrm{c}}\end{array}$ & $\begin{array}{c}1.23 \\
\pm 0.01^{\mathrm{b}}\end{array}$ & $\begin{array}{l}218.8 \\
\pm 0.28^{\mathrm{a}}\end{array}$ & $\begin{array}{c}219.55 \\
\pm 0.07^{\mathrm{a}}\end{array}$ & $\begin{array}{l}37.00 \\
\pm 1.41^{\mathrm{a}}\end{array}$ & $\begin{array}{l}37.00 \\
\pm 1.41^{\mathrm{a}}\end{array}$ \\
\hline
\end{tabular}

The data represent the average value \pm standard deviation of three replicates from each sample. The different letters in the columns (a-b) represent statistically significant differences $(p<0.05)$.

$\mathrm{TPC}$ - total phenolic content. WHC - water holding capacity.

factors. Table 4 shows the changes in the WHC values of yoghurt from fresh and stored samples of different treatments. Control yoghurt exhibited the highest WHC, both when fresh and after 21 days of storage, compared to yoghurt with DEP liposomes. The addition of 5\% DEP liposomes decreased the WHC of yoghurt slightly, compared to the control; the addition of higher percentages of DEP liposomes led to a marked decrease in the WHC of yoghurt, and this decrease is parallel to the percentage of added DEP liposomes. These results indicate that the DEP liposomes weaken the protein network of yoghurt, which results in more serum being released.

Total phenolic content (TPC) of yoghurt fortified with DEP liposomes during storage (fresh and after 21 days). The total phenolic contents of yoghurt samples fortified with DEP liposomes during storage are shown in Table 4. The mean values of TPC of yoghurt samples increased significantly with increasing amounts of added DEP liposome $(P<0.05)$ in fresh yoghurt, and the highest TPC was found in 20\% DEP liposome (208.55 mg Gallic acid/g) compared to plain yoghurt (188.00 mg Gallic acid/g). However, after prolonged refrigerated storage, the mean values of TPC of yoghurt samples fortified with different concentrations of DEP liposome increased, probably due to moisture loss, and were still higher than the control sample. The difference in TPC of yoghurt samples, both when fresh and after 21 days of cold storage, could be explained by the degradation of milk proteins by the proteolytic activity of yoghurt bacteria, resulting in the release of some degradation products capable of reacting with Folin-Ciocalteu reagent (McCue and Shetty, 2004). Also, Lactobacilli are generally considered more proteolytically active than streptococci during milk fermentation and storage (Marshal, 1986). In addition, the degradation of milk proteins may result in the release of phenolic amino acids and non-phenolic compounds such as sugars and proteins, which may interfere with total phenolic evaluation (Ainsworth and Gillespie, 2007).

\section{Texture analysis of yoghurt supplemented with} different concentrations of DEP-loaded liposome.

Table 5 presents the textural parameters of yoghurt fortified with DEP liposome and the control sample. The hardness of yoghurt samples decreased with 
El-Said, M. M., El-Messery, T. M., El-Din, H. M. F. (2018). The encapsulation of powdered doum extract in liposomes and its application in yoghurt. Acta Sci. Pol. Technol. Aliment., 17(3), 235-245. http://dx.doi.org/10.17306/J.AFS.2018.0571

Table 5. Texture analysis of yoghurt supplemented with DEP liposome during storage

\begin{tabular}{llllll}
\hline Samples & $\begin{array}{c}\text { Hardness } \\
\mathrm{N}\end{array}$ & $\begin{array}{c}\text { Springiness } \\
\mathrm{mm}\end{array}$ & Cohesiveness & $\begin{array}{c}\text { Gumminess } \\
\mathrm{N}\end{array}$ & $\begin{array}{c}\text { Chewiness } \\
\mathrm{N} \cdot \mathrm{mm}\end{array}$ \\
\hline Control & $1.20 \pm 0.00^{\mathrm{a}}$ & $4.35 \pm 0.02^{\mathrm{a}}$ & $2.67 \pm 0.02^{\mathrm{a}}$ & $2.90 \pm 0.02^{\mathrm{a}}$ & $0.58 \pm 0.01^{\mathrm{a}}$ \\
5 & $1.10 \pm 0.00^{\mathrm{a}}$ & $0.73 \pm 0.04^{\mathrm{b}}$ & $0.36 \pm 0.01^{\mathrm{b}}$ & $0.49 \pm 0.01^{\mathrm{b}}$ & $0.34 \pm 0.03^{\mathrm{b}}$ \\
10 & $0.95 \pm 0.07^{\mathrm{b}}$ & $0.66 \pm 0.01^{\mathrm{c}}$ & $0.40 \pm 0.01^{\mathrm{c}}$ & $0.39 \pm 0.01^{\mathrm{c}}$ & $0.25 \pm 0.01^{\mathrm{c}}$ \\
15 & $0.95 \pm 0.07^{\mathrm{b}}$ & $0.63 \pm 0.01^{\mathrm{cd}}$ & $0.36 \pm 0.01^{\mathrm{cd}}$ & $0.37 \pm 0.01^{\mathrm{c}}$ & $0.21 \pm 0.01^{\mathrm{c}}$ \\
20 & $0.55 \pm 0.07^{\mathrm{c}}$ & $0.60 \pm 0.01^{\mathrm{d}}$ & $0.47 \pm 0.01^{\mathrm{d}}$ & $0.23 \pm 0.01^{\mathrm{d}}$ & $0.15 \pm 0.01^{\mathrm{d}}$ \\
\hline Control & $1.15 \pm 0.07^{\mathrm{a}}$ & $0.71 \pm 0.01^{\mathrm{a}}$ & $0.46 \pm 0.02^{\mathrm{a}}$ & $0.52 \pm 0.01^{\mathrm{a}}$ & $0.37 \pm 0.01^{\mathrm{a}}$ \\
5 & $1.05 \pm 0.07^{\mathrm{ab}}$ & $0.69 \pm 0.01^{\mathrm{a}}$ & $0.42 \pm 0.01^{\mathrm{a}}$ & $0.38 \pm 0.02^{\mathrm{b}}$ & $0.25 \pm 0.01^{\mathrm{b}}$ \\
10 & $1.05 \pm 0.7^{\mathrm{ab}}$ & $0.58 \pm 0.01^{\mathrm{b}}$ & $0.35 \pm 0.03^{\mathrm{b}}$ & $0.34 \pm 0.01^{\mathrm{b}}$ & $0.18 \pm 0.01^{\mathrm{c}}$ \\
15 & $0.85 \pm 0.07^{\mathrm{b}}$ & $0.56 \pm 0.02^{\mathrm{b}}$ & $0.31 \pm 0.01^{\mathrm{b}}$ & $0.21 \pm 0.01^{\mathrm{c}}$ & $0.12 \pm 0.01^{\mathrm{d}}$ \\
20 & $0.50 \pm 0.14^{\mathrm{c}}$ & $0.25 \pm 0.01^{\mathrm{c}}$ & $0.14 \pm 0.01^{\mathrm{c}}$ & $0.14 \pm 0.01^{\mathrm{d}}$ & $0.06 \pm 0.04^{\mathrm{e}}$ \\
\hline
\end{tabular}

The data represent the average value \pm standard deviation of three replicates from each sample. The different letters in the columns (a-b) represent statistically significant differences $(p<0.05)$.

increasing concentrations of DEP liposome. However, the differences in the hardness of the yoghurt containing 5\% DEP liposome and the control when fresh and after storage were found to be insignificant $(P<0.05)$. Significant decreases $(P<0.05)$ were found in hardness between yoghurts containing 10,15 and $20 \%$ DEP liposome compared to the control. This may be attributed to weakness of the protein network, resulting in less firmness. The changes in the other textural parameters followed a similar trend to hardness. Thus the values of cohesiveness, springiness, gumminess and chewiness decreased with increasing added DEP liposomes. All parameters decreased in the control, whereas the DEP liposome fortified the yoghurt during cold storage, and the changes were most pronounced in the control. Mean values of cohesiveness were lower for yoghurt samples supplemented with DEP liposome than in the control sample; this may be due to the lower strength of their protein-protein interaction bonds. Also, similar changes were found for springiness. Moreover, chewiness and gumminess of the yoghurt supplemented with doum liposome were reduced significantly compared to the control yoghurt.

\section{CONCLUSION}

Doum extract powder was successfully encapsulated in liposomes. The high encapsulation efficiency, particle size, and TEM examination indicate successful encapsulation of up to $1 \%$ DEP. The addition of $5 \%$ DEP liposomes to yoghurt somewhat affected the development of acidity, textural parameters, and water holding capacity of yoghurt, compared to a control. The addition of higher percentages of DEP liposomes markedly affected the functional properties of yoghurt. It is recommended that $5 \%$ DEP liposomes could be added to yoghurt in order to increase its antioxidant activity.

\section{REFERENCES}

Aamer, R. A. (2016). Characteristics of aqueous doum fruit extract and its utilization in some novel products. Ann. Agric. Sci., 61(1), 25-33.

AOAC (2000). Official methods of analysis. Arlington, VA: Association of Official Analytical Chemists.

Aboshora, W., Lianfu, Z., Dahir, M., Qingran, M., Qingrui, S., Jing, L., Al-Haj, N. Q. M. (2014). Effect of extraction 
method and solvent power on polyphenol and flavonoid levels in Hyphaenethebaica L. Mart (Arecaceae) (doum) fruit, and its antioxidant and antibacterial activities. Trop. J. Pharm. Res., 13, 2057-2063. http://dx.doi. org/10.4314/tjpr.v13i12.16

Arslan, S., Özel, S. (2012). Some properties of stirred yogurt made with processed grape seed powder, carrot juice or a mixture of grape seed powder and carrot juice. Milchwissenschaf, 67, 281-285.

Ainsworth, E. A., Gillespie, K. M. (2007). Estimation of total phenolic content and other oxidation substrates in plant tissues using Folin-Ciocalteu reagent. Nat. Protoc., 2(4), 875-877. http://dx.doi.org/10.1038/nprot.2007.102

Brand-Williams, W., Cuvelier, M. E., Berset, C. (1995). Use of a free radical method to evaluate antioxidant activity. Lebensm. Wiss. Technol., 28, 25-30. https://doi. org/10.1016/S0023-6438(95)80008-5

Chen, C. W., Ho, C. T. (1995). Antioxidant properties of polyphenols extracted from green and black tea. J. Food Lipids, 2, 35-46. https://doi. org/10.1111/j.1745-4522.1995.tb00028.x

El-Abbadi, N. H., Dao, M. C., Meydani, S. N. (2014). Yogurt: role in healthy and active aging. Am. J. Clin. Nutr., 99(5), 1263S-1270S. http://dx.doi.org/10.3945/ ajcn.113.073957

Eldahshan, O., Ayoub, N., Singab, A., Al-Azizi, M. (2008). Potential superoxide anion radical scavenging activity of doum palm (Hyphaenthebaica L.) leaves extract. Rec. Nat. Prod., 2, 83-93.

Eldahshan, O., Ayoub, N., Singab, A., Al-Azizi, M. (2009). Potential antioxidant phenolic metabolites from doum palm leaves. Afr. J. Pharm. Pharmacol., 3, 158-164.

Falleh, H., Ksouri, R., Lucchessi, M. E., Abdelly, C., Magné, C. (2012). Ultrasound-assisted extraction: effect of extraction time and solvent power on the levels of polyphenols and antioxidant activity of Mesembryanthemum edule L. Aizoaceae shoots. Trop. J. Pharm. Res., 11(2), 243-249. http://dx.doi.org/10.4314/tjpr.v11i2.10

Guldiken, B., Gibis, M., Boyacioglu, D., Capanoglua, E., Weiss, J. (2017). Impact of liposomal encapsulation on degradation of anthocyanins of black carrot extract by adding ascorbic acid. Food Funct., 8, 1085-1093. http:// dx.doi.org/10.1039/c6fo01385f

Gibis, M., Vogt, E., Weiss, J. (2012). Encapsulation of polyphenolic grape seed extract in polymer coated liposomes. Food Funct., 3, 246-254. http://dx.doi. org/10.1039/c1fo10181a

Gültekin-Özgüven, M., Karadağ, A., Duman, S., Özkal, B., Özçelik, B. (2016). Fortification of dark chocolate with spray dried black mulberry (Morus nigra) waste extract encapsulated in chitosan-coated liposomes and bioaccessability studies. Food Chem., 201, 205-212.

Habib, D. F., Michael, H. N., Salib, J. Y., Ahmed, N. M., Agaibyi, M. H. (2014). Hypolipidemic efficacy of hyphaenethebaica (doum) in experimental nephrotic syndrome. IJP, 4, 28-34.

Hsu, B., Coupar, I. M., Ng, K. (2006). Antioxidant activity of hot water extract from the fruit of the doum palm, Hyphaene thebaica. Food Chem., 98, 317-328. https:// doi.org/10.1016/j.foodchem.2005.05.077

Haratifar, S., Corredig, M. (2014). Interactions between tea catechins and casein micelles and their impact on renneting functionality. Food Chem., 143, 27-32. https:// doi.org/10.1016/j.foodchem.2013.07.092

Jayaprakasha, G. K., Singh, R. P., Sakariah, K. K. (2001). Antioxidant activity of grape seeds (Vitis vinifera). Food Chem., 73, 285-290. https://doi.org/10.1016/ S0308-8146(00)00298-3

Katalinic, V., Milos, M., Kulisic, T., Jukic, M. (2006). Screening of 70 medicinal plant extracts for antioxidant capacity and total phenols. Food Chem., 94, 550-557. https://doi.org/10.1016/j.foodchem.2004.12.004

Ksouri, R., Falleh, H., Megdiche, W., Trabelsi, N., Mhamdi, B.,Chaieb, K., ..., Abdelly, C. (2009). Antioxidant and antimicrobial activities of the edible medicinal halophyte Tamarix gallica L. and related polyphenolic constituents. Food Chem. Toxicol., 47(8), 2083-2091. https://doi.org/10.1016/j.fct.2009.05.040

Kim, K. H., Tsao, R., Yang, R., Cui, S. W. (2006). Phenolic acid profiles and antioxidant activities of wheat bran extracts and the effect of hydrolysis conditions. Food Chem., 95, 466-473. https://doi.org/10.1016/j. foodchem.2005.01.032

IDF (1991). Rheological and fracture properties of cheeses. IDF standard 268. Brussels, Belgium: International Dairy Federation.

Illupapalayam, V. V., Smith, S. C., Gamlath, S. (2014). Consumer acceptability and antioxidant potential of probiotic yogurt with spices. LWT, 55(1), 255-262. https:// doi.org/10.1016/j.lwt.2013.09.025

Marshal, V. (1986). The microflora and production of fermented milks. Prog. Ind. Microbiol., 23, 1-44.

Mozafari, M. R., Johnson, C., Hatziantoniou, S., Demetzos, C. (2008). Nanoliposomes and their applications in food nanotechnology. J. Liposom. Res., 18, 309-327. http:// dx.doi.org/10.1080/08982100802465941

McCue, P., Shetty, K. (2004). Inhibitory effects of rosmarinic acid extracts on porcine pancreatic amylase in vitro. Asia Pac. J. Clin. Nutr., 13, 101-106. 
El-Said, M. M., El-Messery, T. M., El-Din, H. M. F. (2018). The encapsulation of powdered doum extract in liposomes and its application in yoghurt. Acta Sci. Pol. Technol. Aliment., 17(3), 235-245. http://dx.doi.org/10.17306/J.AFS.2018.0571

Nothlings, U., Murphy, S. P., Wilkens, L. R., Henderson, B. E., Kolonel, L. N. (2007). Flavonols and pancreatic cancer risk the multiethnic cohort study. Amer. J. Epid., 166(8), 924-931. http://dx.doi.org/10.1093/aje/kwm172

Costa, K. K. F. D., Pertuzatti, P. B., De Oliveira, T. F., Caliari, M., Júnior, M. S. S. (2017). Syneresis and chemical characteristics of fermented rice extract with probiotic bacteria and waxy maize starch. Food Sci. Technol., 37, 4, 640-646. http://dx.doi.org/10.1590/1678-457x.29216

Ozdal, T., Capanoglu, E., Altay, F. (2013). A review on protein phenolic interactions and associated changes. Food Res. Inter., 51, 954-970. https://doi.org/10.1016/j. foodres.2013.02.009

Rashidinejad, A., Birch, E. J., Sun-Waterhouse, D., Everet, D. W. (2013). Effects of catechin on the phenolic content and antioxidant properties of low-fat cheese. Inter. J. Food Sci. Techn., 48, 2448-2455. https://doi. org/10.1111/ijfs. 12234

Schrooyen, P. M. M., Van der Meer, R., Kruif, C. G. (2001). Microencapsulation: its application in nutrition. Proc. Nutr. Soc., 60, 475-479. https://doi.org/10.1079/ PNS2001112

SPSS (1999). SPSS for Windows. Release 10.0 (27 Oct., 1999). Standard version. Copyright SPSS Inc., 1989-1999.
Sun-Waterhouse, D., Zhou, J., Wadhwa, S. S. (2013). Drinking yogurts with berry polyphenols added before and after fermentation. Food Cont., 32, 450-460. https://doi. $\operatorname{org} / 10.1016 /$ j.foodcont.2013.01.011

Saint-Eve, A., Lévy, C., Martin, N., Souchon, I. (2006). Influence of proteins on the perception of flavored stirred yogurts. J. Dairy Sci., 89(3), 922-933. http://dx.doi. org/10.3168/jds.S0022-0302(06)72157-9

Saloko, S., Darmadji, P., Pranoto, Y., Anal, A. K. (2013). Encapsualtion of coconut shell liquid smoke in chitosanmaltodextrin based nanoparticles. Int. Food Res. J., 20(3), 1269-1276.

Takachi, R., Inoue, M., Ishihara, J., Kurahashi, N., Iwasaki, M., Sasazuki, S., Iso, H., Tsubono, Y., Tsugane, S. (2008). Fruit and vegetable intake and risk of total cancer and cardiovascular disease Japan public health center-based prospective study. Amer. J. Epid., 167(1), 59-70. http://dx.doi.org/10.1093/aje/kwm263

Thompson, A. K., Singh, H. (2006). Preparation of liposomes from milk fat globule membrane phospholipids using a microfluidizer. J. Dairy Sci., 89, 410-419. http:// dx.doi.org/10.3168/jds.S0022-0302(06)72105-1 